\title{
Drivers and Barriers for Going Green: Perceptions from the Business Practitioners in Malaysia
}

\author{
S-P. LOKE ${ }^{1 *}$, K. KHALIZANI ${ }^{2}$, S. ROHATI ${ }^{1}$ AND A. SAYAKA ${ }^{3}$
}

\begin{abstract}
The changes of global environmental conditions have placed great challenges to governments and societies. While it is not easy for the companies to go green, we need a renewed concern for our environment in order to revive the nation's economic growth, social cohesion and ecological balances. This article identifies the drivers and barriers for the business industry to adopt green practices. A total of 571 business companies from the Perak State participated in this study. Four variables: (1) Regulations $(\beta=0.159, \mathrm{p}<0.05)$; (2) Social responsibility $(\beta=0.201, \mathrm{p}<0.05)$; (3) Pro-environmental organizational culture $(\beta=0.389, \mathrm{p}<0.01)$; and (4) Organizational supports $(\beta=0.369, \mathrm{p}<0.01)$ were found to significantly affect the company's green initiatives. The results indicated that the main internal barriers were: it lacked of financial resources (66.2\%) and skilled staff (63.9\%); whereas the main external barriers were: the penalty imposed were not severe enough for making any extra efforts $(64.8 \%)$ and the penalty was light for violation of environmental regulations $(63.2 \%)$. This research had implications for the academics, practitioners and policy makers. It provided greater insights into the green practices in Malaysian firms. The research findings also urged the local governments to greatly enhance regulatory scrutiny on the production and manufacturing industries.
\end{abstract}

Key words: Green practices; going green; environmental strategy; regulations; social responsibility; barriers; industries

Today, all nations - regardless of whether they are developed economies or emerging economies - are challenged with highly visible ecological problems (Hart 2000). Pollution and climate changes have impacted not only the physical environment, but also the terrestrial and marine ecosystem as well as the society at large. While rapid economic development and population growth are some of the root causes, business organizations are often blamed mainly for these environmental problems.

Malaysia has become a more polluted country as reported by the Climate Change Performance Index (CCPI) 2014. This CCPI generally measures the climate protection performance of 61 countries aiming to enhance transparency in international climate politics. Malaysia together with countries like China and Singapore, appeared in the bottom-ranked group of newly industrialised countries for being one of the largest carbon dioxide emitters (Figure 1).

Although Malaysia has climbed from 55th position in 2013 to 51 st this year, among the ASEAN member countries including India, China, Japan and Korean Republic, it has scored the lowest position based on the score of CCPI (Figure 2).

\footnotetext{
${ }^{1}$ Faculty of Business Management, Universiti Teknologi MARA, Perak Campus, Bandar Seri Iskandar, 36210 Bota, Perak

${ }^{2}$ Faculty of Business Management, Universiti Teknologi MARA Kedah, Kedah Campus, 08400 Merbok, Kedah

${ }^{3}$ Institute Darul Rizduan, B-1-9, Greentown Suria, Jalan Dato' Seri Ahmad Said, 30450 Ipoh, Perak

*Corresponding author (e-mail: lokesp@gmail.com; loke4529@perak.uitm.edu.my)
} 


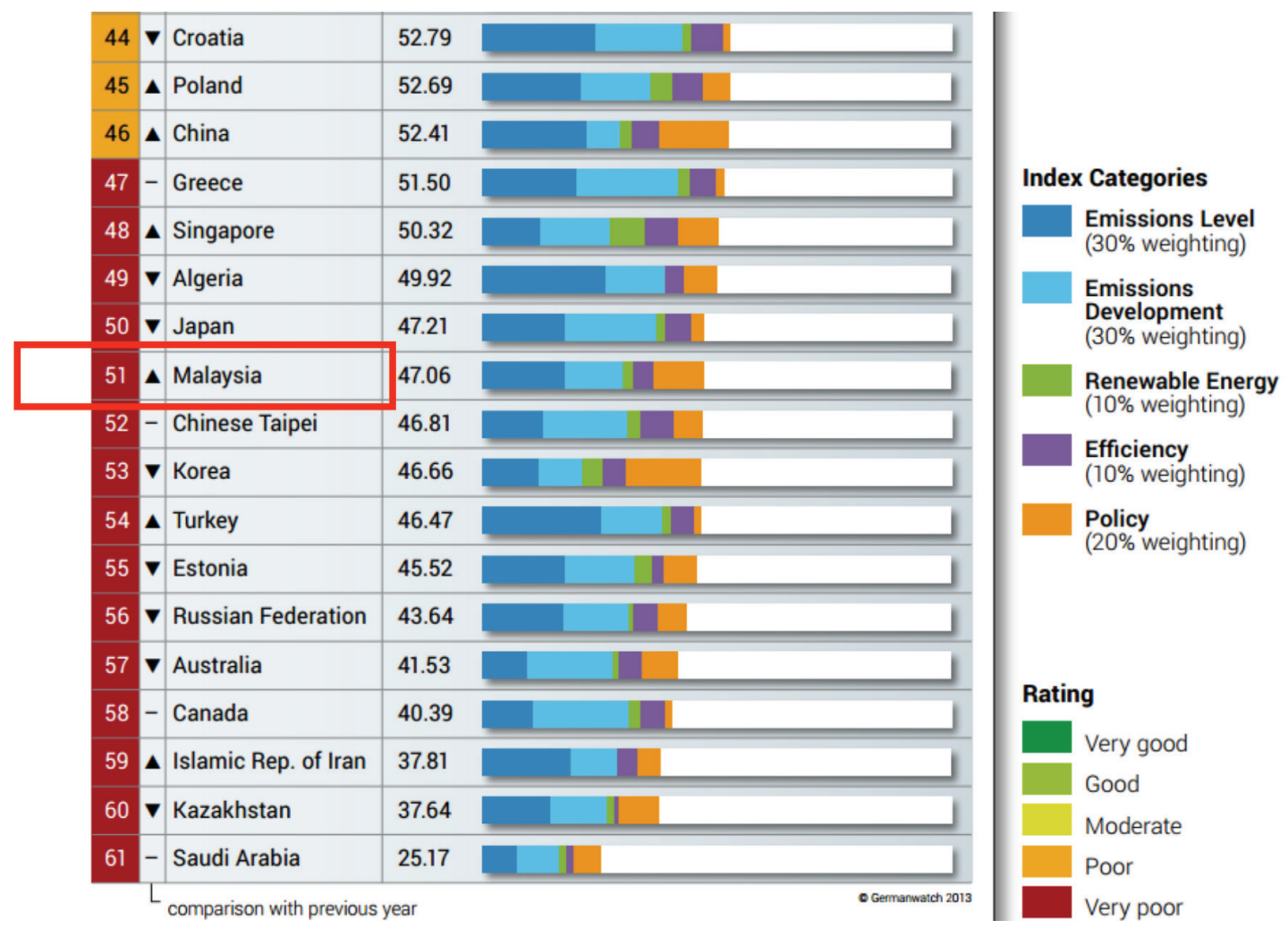

Figure 1. Climate Changes Performance Index for Newly Industrialized Countries (CCPI 2014).

\begin{tabular}{|c|c|c|c|c|c|c|c|c|}
\hline Rank & Country & Score & Rank & Country & Score & Rank & Countrv & Score \\
\hline 30 & India & 57.16 & 46 & China & 52.71 & 51 & Malaysia & 47.06 \\
\hline 34 & Indonesia & 56.24 & 48 & Singapore & $50.3 z$ & $x<$ & Cninese Talper & 40.81 \\
\hline 38 & Thailand & 54.51 & 50 & Japan & 47.21 & 53 & Korea & 46.66 \\
\hline
\end{tabular}

Figure 2. Climate Changes Performance Index for ASEAN countries including India, China, Japan and Korean (CCPI 2014).

According to Perry and Singh (2001), the environmental problems of Malaysia are concentrated in the main centres of economic activity such as Kuala Lumpur, Klang Valley, Penang and Johor. A study conducted almost two decades ago on 3889 Malaysian manufacturing industries revealed that industries with foreign investment dominant in electronics and chemicals had higher compliance rate under the respective regulations (Perry \& Singh 2001). Although as early as in 1974, the regulation framework was already in place to mitigate the industrial pollution problems, the monitoring and enforcement mechanisms were found to be limited. 
Chen, Shih, Shyur, and Wu (2012) argued that the increased public attention of sustainability and environmental issues and those regulations such as Waste Electrical Electronic Equipment and Eco-design Requirement for Energy Using Product were established. Undoubtedly, the proliferation of research on renewable energy and environmental protection is largely due to the impacts of climate change and declining fossil fuel reserves. Hong, Roh and Rawski (2012) added that there is an urgency for firms to be responsive towards ecological or natural environment in order to sustain and preserve the wealth of natural resources for our next generations.

\section{LITERATURE REVIEW}

Businesses have increasingly embraced green concept in their marketing efforts (Raska $\&$ Shaw 2012). David (2012) added that consumers today are attracted to businesses that preserve nature's ecological balance and foster a clean and healthy environment. Thus, any green initiative should be sufficiently visible for gaining attention from the customers as there is an increased demand in green practices from them (Andic, Yurt \& Baltacioglu 2012). For example, ElTayeb, Zailani and Jayaraman (2010) found that customer pressure is one of the drivers for green purchasing in Malaysia.

The triple focus on green productivity environment, quality, and profitability is aimed to ensure long-term survival of the firms (Diabat \& Govidan 2011). More interestingly, smart companies could actually use environmental strategy to innovate, create value, and build competitive advantages. The business world has created numerous opportunities of innovation which firms have become the leading of sustainability movement in many ways.

Environmental leaders see their business through an environmental lens, finding opportunities to cut costs, reduce risk, drive revenues, and enhance intangible value. They build deeper connections with customers, employees, and other stakeholders. Their strategies reveal a new kind of sustained competitive advantages that we call Eco-Advantage (Esty \& Winston 2009, p.14).

As highlighted by the authors of Green to Gold, the eco-advantage mindset is a powerful motivator to help companies to face challenges and find new ways to seize advantages. In fact, the Green Wave has swept across the business world forcing the companies to react and these trends and forces will continue to evolve. Being eco-efficient is one of the crucial determinants to survive in a cost-conscious world. Such restructured landscape requires a new refined business strategy. Some companies and sectors have responded faster than others. Companies must be creative to break out of the pack. This is because those that do not will struggle to remain competitive in the marketplace.

The sustainability and sustainable development defined by the World Commission on Environment and Development as "meeting the needs of the present without compromising the ability of future generations to meet their own needs" (Loucks, Martens \& Cho, 2010). Similarly, Kleindorfer, Singhal, and Wassenhove (2005) stated that sustainability is the co-ordination of resources in meeting people's wants for a satisfying life, besides the necessity to respect the bottom line of three "Ps", which are planet, people and profit.

Environmental sustainability is related to the proper and efficient use of natural resources over time whereas the firm sustainability refers to its ability to gain long-term returns. These two concepts are closely related because environmental principles and guidelines can generate green innovations which are in fact, reducing cost, rising up the productivity and increasing the companies' competitive 
capabilities. Therefore, many different theories and empirical research have been dedicated to explore on the implementation and effects of green practices such as eco-design, cleaner production practices and waste management, environmental purchasing, and green/ reverse logistics.

In Malaysia, new controls on hazardous waste have been added to the Environmental Quality (Amendment) Act 1996 (Perry \& Singh (2001). Sani (1999) stated that this amendment has included substantial increases to penalties for a range of environmental offenses as to exert compliance pressure on the industry. Similarly, the Malaysian government has demonstrated an increased willingness to accept outside influence on environmental performance. For example, the international criticisms on domestic forestry have resulted in the establishment of the National Timber Certification Centre with the industry partners in order to create the Malaysian Criteria and Indicators for Sustainable Forest Management. Perry and Singh (2001) added that the growing public awareness and media coverage have placed increased emphasis on these environmental issues in the Seventh Malaysia Five-Year Plan.

Indeed, we must stabilize and reduce the environmental burdens in order to achieve sustainability. Under the New Economic Model, the Malaysian government has embarked on the green initiatives as one of the nation's new economic drivers and transforming the country to become a high income nation by year 2020. While driving Malaysia towards greater economic development, these initiatives provide a valuable framework on conservation and protection of the nation's heritage and natural environment.

Meanwhile, the National Green Technology Policy was successfully launched by the Prime Minister of Malaysia on 24 July 2009. The National Green Technology Policy is built on four pillars - Energy, Environment, Economy and Social. Green Technology is aimed to be the key driver in accelerating the national economy and promoting sustainable development in Malaysia. The Malaysia Green Technology Corporation or known as GreenTech Malaysia has been striking not only to develop green technology roadmap and standards, but also to promote an environmental friendly living culture at large.

We know anecdotally better environment management strategy enhances the competitiveness of a firm. The environmental mismanaging, however, can damage the brand reputation, destroy its competitiveness and sometimes can knock off the value of the company overnight. As such, a more positive attitude towards environmental issues, e.g. the adoption of green manufacturing would institutionalize the companies' awareness on environmental concerns which could bring indirect benefits through better quality of their manufacturing operations.

Businesses face challenges in implementation of environmental initiatives especially when striking the balance of profitability and corporate social responsibility. Pressures came from various sources so that their products are environmental friendly (ElTayeb et al. 2010). According to Orsato (2006), the difficult aspect of environmental initiatives is the basic reasoning on environmental protection because such a move is strongly known as a public good. Although literature demonstrates that effective environmental management generate eco-advantages for the companies, Esty and Winston (2009) argued that capturing these advantages require expertise and capabilities to master the whole range of related issues. Often, the company has struggled to push for green effort due to private costs of prevention and clean up which lead to higher operational costs and thus reduces its industrial competitiveness (Porter \& Van Der Linde 2000). 
The environmental effort does not always produce superior results. They may fail because of poor planning, an absence of commitment and not having the right people in the key roles. Some of the business strategies did not work well due to focusing on the wrong issues, marketplace is misunderstood, the customer responses towards green products are interpreted wrongly and therefore the implementation on the environmental thinking in the business was not successful.

Nevertheless, the consciousness of issues on environmental sustainability and the need to comply with the standards are critical to drive companies to embark on greater environmental commitment. However, there is a clear lack of empirical research in emerging economies. We need a greater understanding on the awareness of business industry's environmental management strategy particularly within the Malaysia setting. Based on this notion, the objective of this study was two-fold: (1) To examine the factors influencing the business firms' attitude towards environmental commitment, and (2) To identify the barriers that inhibit them to go green. Understanding the fundamental factors for business practitioners to go green is indeed crucial because these identified key factors can serve as a springboard to better promote the firm's commitment to go green. It is hoped that the research findings on sustainable development practices can shed lights for the nation especially for the State Governments to better manage the balance between economic growth and ecological sustainability.

\section{METHODOLOGY}

\section{Research Design and Sampling}

The study was designed to test a structural model whether these variables namely Regulations, Social Resposbility, Customer Pressure, Pro-Environmental Organizational Culture and Organizational Supports would lead to a greater level of company's commitment to venture into green initiatives. These variables were identified through a comprehensive review of the relevant literature. The research instrument was adapted from previous studies. A focus group was conducted with six industry panels to validate the questionnaire before data collection.

In this study, managers and executives from the manufacturing firms located within the state of Perak were targeted. The firms were selected from the Federation of Malaysian Manufacturers Directory 2013. Manufacturing firms were chosen because operations of these industrial companies are frequently and directly related to the environment - from pollution control to the most innovative green initiatives.

Questionnaires were personally handdelivered to a sample of 1000 randomly selected companies located in the state of Perak. The researchers also contacted SME Corp. (Perak office) and Federal of Manufacturing Malaysia (FMM) (Perak Branch) to seek for their members' participation in this study. Data collection was carried out from August to October 2013. Based on these 1000 questionnaires originally distributed, a total of 571 of them were found completed and usable, yielding a response rate of $57.1 \%$.

\section{Profiling of the Participating Firms}

There were a total of 571 companies (FMM directory and SMEs in Perak) which participated in this research: 561 manufacturer and 10 services companies. Majority of the participating companies were from the electrical, machinery and apparatus industries (31.2 per cent) followed by the food products and beverage industries ( 24.5 per cent) (Figure 3).

The participating companies mostly concentrated their businesses on both local and international markets with $63.8 \%$. The 


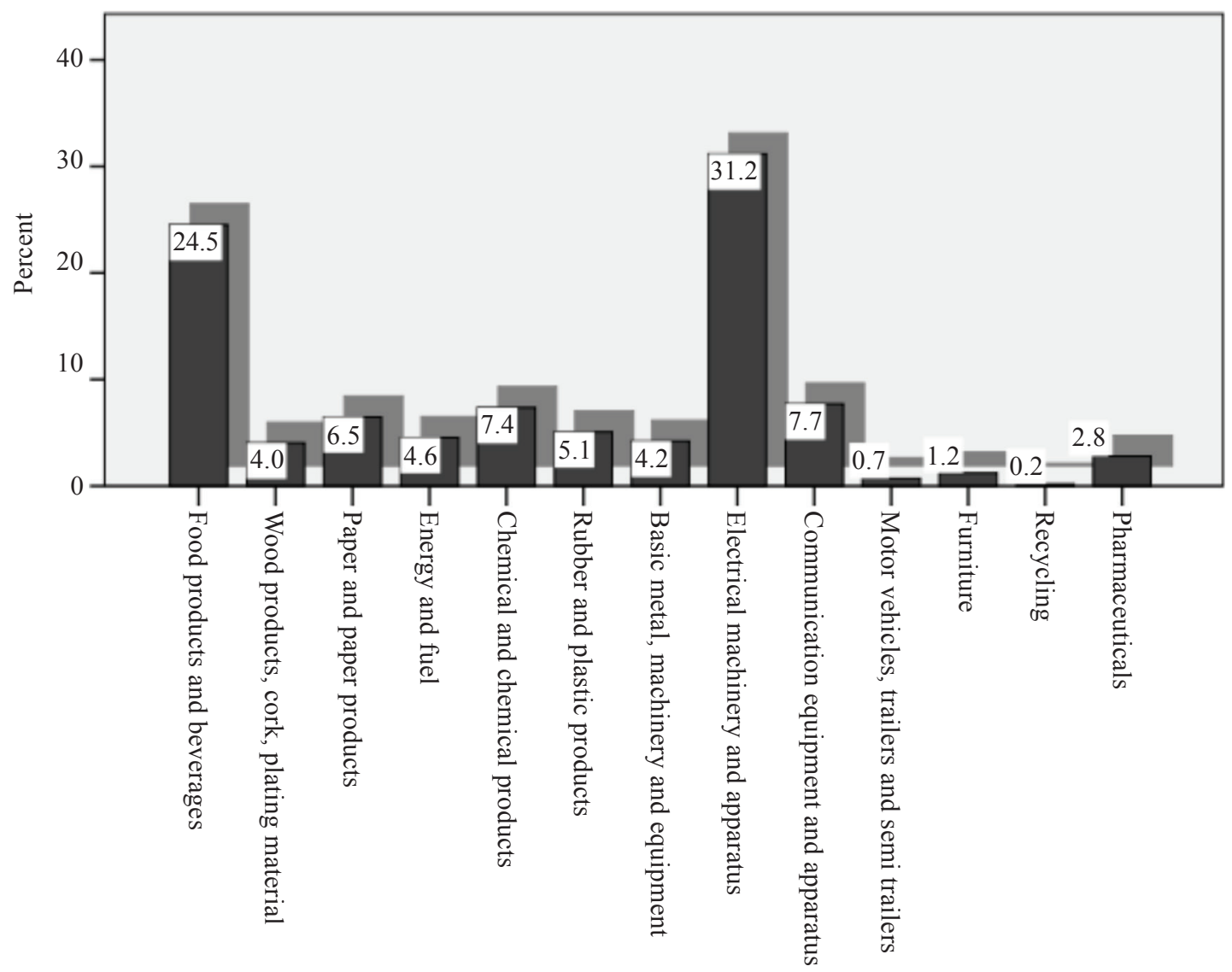

Figure 3. Industrial category of the participating firms.

participating companies were Malaysian-owned firms $(78.6 \%)$ whereas the foreign-owned firms accounted for approximately 20 percent, and joint ventures accounted for less than 1 percent. Also, we found that most of these companies fell into the category of having workers between 21 to 100 employees and between 101 to 200 employees with $28.7 \%$ and $27.8 \%$, respectively. In addition, when the responding companies were asked to indicate their certification of ISO for quality and environmental management, it was found that adoption for quality was much greater as compared to environmental management such as ISO 14001 (Environmental Management System (Specifications with guidance for use).

\section{DATA ANALYSIS}

Before conducting the analysis for structural modelling, the validity and the relability of the survey instrument were generated. Data used for final data analysis was 562 after the data with outliners were eliminated. As shown in Table 1, the results indicated that all values for the validity and reliability tests were within the acceptable range. Except for item RG6, all factor loadings for each indicator were $>0.5$ indicating a high convergent validity. All cronbach alpha values were $>0.70$ demostrating a high consistency of the items used to measure each variable (i.e. regulations, social responsibility, customer pressure, pro-environmental organizational cultures, 
Table 1 . Results for validity and reliability test $(\mathrm{n}=562)$.

\begin{tabular}{|c|c|c|c|c|}
\hline Variables and items & Indicators & Factor loadings & Total items & Cronbach Alpha \\
\hline \multirow[t]{6}{*}{ Regulations } & RG1 & 0.69 & 6 & 0.807 \\
\hline & RG2 & 0.78 & & \\
\hline & RG3 & 0.71 & & \\
\hline & RG4 & 0.66 & & \\
\hline & RG5 & 0.52 & & \\
\hline & RG6 & 0.49 & & \\
\hline \multirow[t]{7}{*}{ Social responsibility } & SR1 & 0.61 & 7 & 0.811 \\
\hline & SR2 & 0.63 & & \\
\hline & SR3 & 0.64 & & \\
\hline & SR4 & 0.62 & & \\
\hline & SR5 & 0.70 & & \\
\hline & SR6 & 0.59 & & \\
\hline & SR7 & 0.53 & & \\
\hline \multirow{6}{*}{ Customer Pressure } & $\mathrm{CP} 1$ & 0.63 & 6 & 0.801 \\
\hline & $\mathrm{CP} 2$ & 0.61 & & \\
\hline & $\mathrm{CP} 3$ & 0.70 & & \\
\hline & $\mathrm{CP} 4$ & 0.67 & & \\
\hline & $\mathrm{CP} 5$ & 0.61 & & \\
\hline & CP6 & 0.58 & & \\
\hline \multirow{7}{*}{$\begin{array}{l}\text { Pro-environmental } \\
\text { organizational cultures }\end{array}$} & PE1 & 0.52 & 7 & 0.814 \\
\hline & PE2 & 0.65 & & \\
\hline & PE3 & 0.66 & & \\
\hline & PE4 & 0.72 & & \\
\hline & PE5 & 0.73 & & \\
\hline & PE6 & 0.51 & & \\
\hline & PE7 & 0.57 & & \\
\hline \multirow[t]{7}{*}{ Organizational support } & OS1 & 0.64 & 7 & 0.800 \\
\hline & OS2 & 0.65 & & \\
\hline & OS3 & 0.63 & & \\
\hline & OS4 & 0.55 & & \\
\hline & OS5 & 0.61 & & \\
\hline & OS6 & 0.64 & & \\
\hline & OS7 & 0.50 & & \\
\hline \multirow{5}{*}{$\begin{array}{l}\text { Green responsive } \\
\text { initiatives (GRI) }\end{array}$} & GRI1 & 0.57 & 5 & 0.782 \\
\hline & GRI2 & 0.62 & & \\
\hline & GRI3 & 0.59 & & \\
\hline & GRI4 & 0.63 & & \\
\hline & GRI5 & 0.59 & & \\
\hline
\end{tabular}

Note: GRI measures the company's willingness and current efforts to go green. 
organizational supports and green responsive initiative. Thus, it was concluded that the survey instrument for measuring the variables were valid and reliable.

\section{Structural Model Evaluation}

Using the SPSS AMOS, the structural model was generated to examine these critical factors: regulations, social responsibility, pro-environmental organizational culture, organizational support and customer pressure on the company's proactiveness in environmental commitment. In this study, multiple fit indices were used: (1) chi-square $\left(\chi^{2}\right)$; statistics to the degree of freedom $(d f)$; (2) the Comparative Fit Index (CFI); and (3) RMSEA (Root Mean Square error of approximation) as suggested by Hair et al. (2010). The goodness of fit index measures if the model was adequately fit.

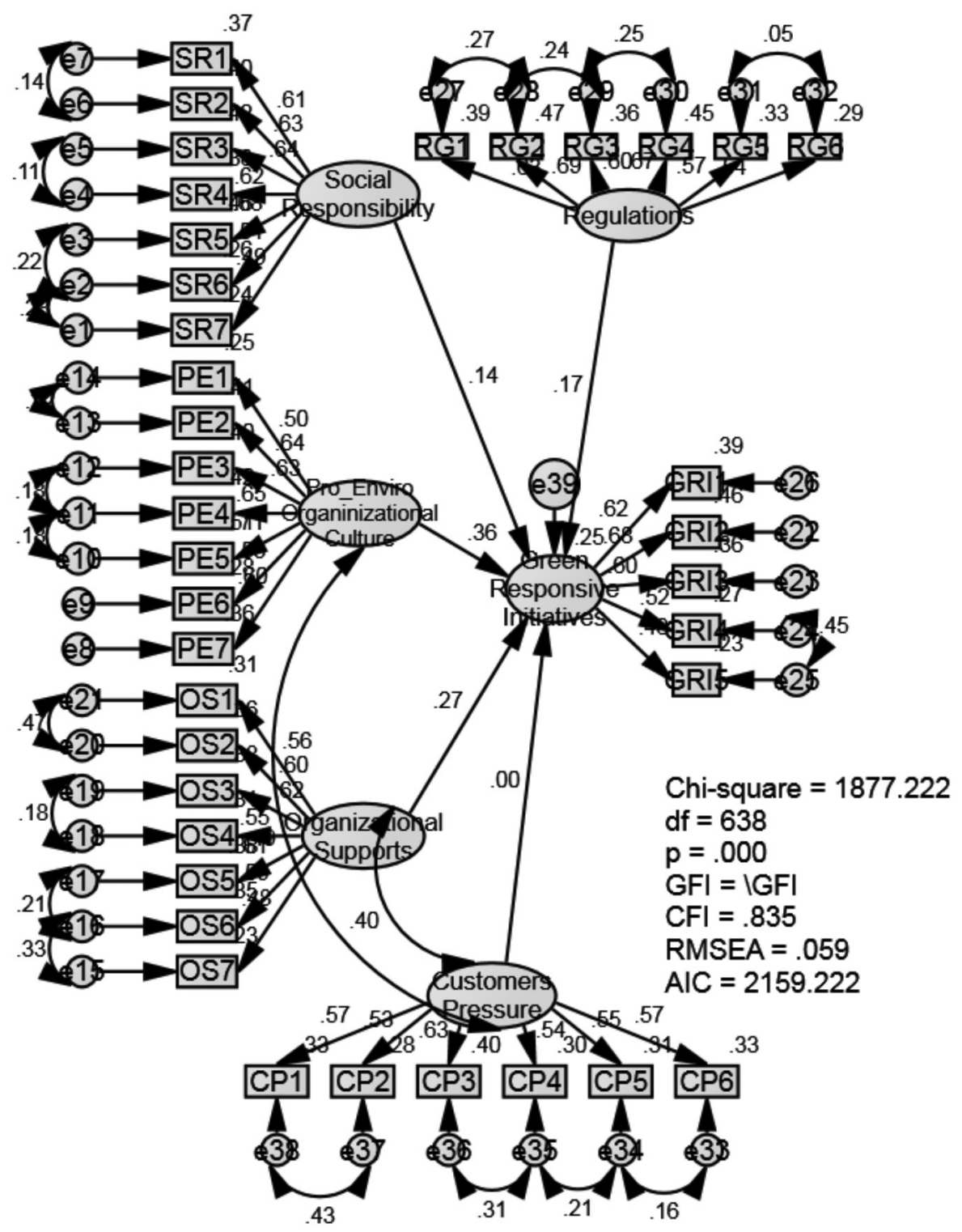

Figure 4. The path diagram for structural model $(\mathrm{n}=562)$. 
The $\chi^{2}$ statistics to $d f$ should be less than 3; goodness of fit indexes such as GFI, CFI and NFI should be as close to 1.00 . The error indexes such as RMSEA and RMR should be as minimum as possible and values ranging 0.05 to 0.08 were deemed accepted. As shown in Figure 4, the results of the structural model analysis was deemed to have a reasonable good fit for the data collected [chi-square $\left(\chi^{2}\right)=1872.222$; degree of freedom $(d f)=6338$; chi-square $\left(\chi^{2}\right) / d f=2.934 ; \mathrm{CFI}=0.835$; RMSEA $=0.059]$.

\section{Drivers for Business to Go Green}

The results have revealed that that only four variables: (1) Regulations $(\beta=0.159, \mathrm{p}<0.05)$;

(2) Social responsibility $(\beta=0.201, p<0.05)$;

(3) Pro-environmental organizational culture
( $\beta=0.389, p<0.01)$; and (4) Organizational support $(\beta=0.369, p<0.01)$ had significantly impacted the company's Green responsive initiative (GRI). However, customer pressure was not the driver that motivated the business industries in Perak to adopt go green initiatives.

\section{Barriers for Business to Go Green}

As illustrated in Table 2, a total of 18 barriers that determining the low commitments towards the environmental protection were identified.

These 18 factors were then divided into both internal and external barriers. The internal barriers were grouped into three categories: (1) Resources, (2) Implementation, and (3) Attitudes and company cultures. In this study, both human and financial resources were

Table 2. Internal and external barriers to go green.

\begin{tabular}{|c|c|c|c|}
\hline & Resources & Implementation & $\begin{array}{l}\text { Attitudes and } \\
\text { company culture }\end{array}$ \\
\hline $\begin{array}{l}\text { Internal } \\
\text { Barriers }\end{array}$ & $\begin{array}{l}\text { - Excessive financial } \\
\text { constraints. } \\
\text { - Lack of management } \\
\text { commitment and/or } \\
\text { supports. } \\
\text { - Lack of engagement/ } \\
\text { commitment from staff. } \\
\text { - Lack of time and } \\
\text { resources to focus on } \\
\text { environmental issues. } \\
\text { - Insufficient training } \\
\text { regarding the } \\
\text { importance of pro- } \\
\text { environmental } \\
\text { behaviour. } \\
\text { - Lack of availability of } \\
\text { skilled staff. }\end{array}$ & $\begin{array}{l}\text { - Unclear leadership } \\
\text { strategy and goals towards } \\
\text { environmental issues. } \\
\text { - Unclear responsibility } \\
\text { regarding who is in charge } \\
\text { of environmental policy/ } \\
\text { practice. } \\
\text { - Lack of clarity } \\
\text { among line managers } \\
\text { regarding whether they } \\
\text { are responsible for } \\
\text { environmental issues. }\end{array}$ & $\begin{array}{l}\text { - Focuses on cost savings. } \\
\text { - Prioritizes on } \\
\text { commercial needs above } \\
\text { environmental concerns. } \\
\text { - Complies with minimum } \\
\text { criteria set by the relevant } \\
\text { authority in order to } \\
\text { lower the overall costs. } \\
\text { - Low awareness on } \\
\text { environmental issues. } \\
\text { - All pro-environmental } \\
\text { efforts were way too } \\
\text { expensive to carry out. } \\
\text { - Lack of organizational } \\
\text { concern for environmental } \\
\text { sustainability. }\end{array}$ \\
\hline $\begin{array}{l}\text { External } \\
\text { Barriers }\end{array}$ & \multicolumn{3}{|c|}{$\begin{array}{l}\text { - Insufficient incentives in place to encourage environmental behavior. } \\
\text { - Penalty for violation of government environmental legislations was light. } \\
\text { - Penalty for violation of government environmental legislations was not severe enough } \\
\text { for making any extra efforts. }\end{array}$} \\
\hline
\end{tabular}


cited to be the major barriers for the company to go green. The financial constraint was the frequent reason why the company was having unfavourable attitude towards greater environmental management efforts. They strongly believed that the implementation of these green practices did not only cut into their profits but also required higher maintenance costs.

We found that there were companies that were more open and willing to go green, but the lack of specialized and technical skills had pulled them back. The belief of the management on the derived benefits from environmental practices would ultimately determine the level of commitment towards green efforts. This is because such commitment would create a climate to either deprive or support the environmental management e.g. consistency of these top management supports, revision of company's priority and allocation of resources. Thus, implementation process could be greatly interrupted without an appropriate corporate culture and full support from the management.

The shortcomings in the governmental framework were also found to have hindered the company to have greater commitment in green practices. The penalty for violation of environmental legislations was said to be light and did not warrant extra efforts from the management. Thus, the company often undertake the bare minimum to fulfil legislation requirements. While there were financial initiatives offered by the Malaysian government such as grants and corporate tax reductions to promote greater green initiatives, the respondents from the focus group had highlighted that these incentives were considered to be a weak motivator.

Figure 5 illustrates the top five barriers that inhibit the company to go green which were drawn from both the internal and external barriers. The percentage was derived from the scores on "very significant" and "significant" when the responding companies were asked to indicate the extent of these challenges they faced in initiating green efforts.

\section{DISCUSSION AND RECOMMEDATIONS}

Based on the research findings, it was found that the business industries faced both internal and external barriers when seeking to address their environmental issues and to embark on green practices. While the results had showed

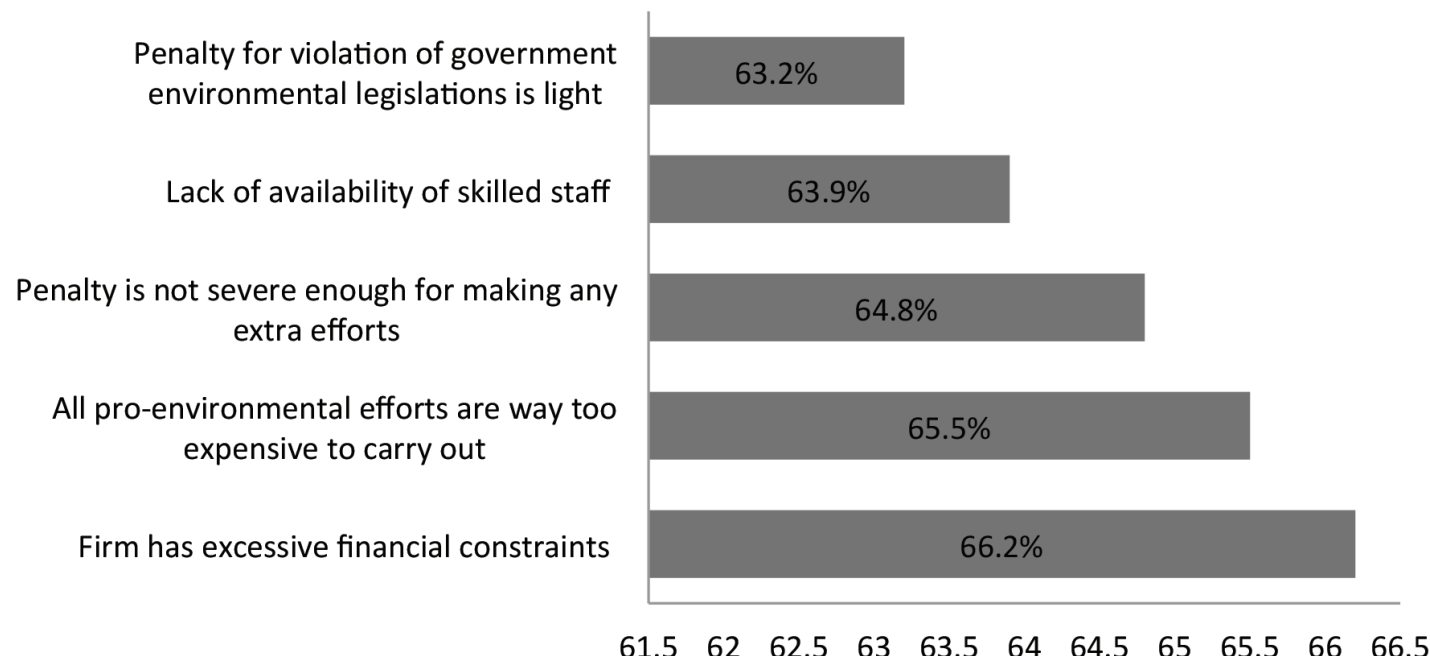

Figure 5. Top five barriers for participating firms to go green $(n=571)$. 
internal barriers such as lack of financial resources and skilled staff were of great hindrance, the participating firms also indicated that the penalty for violating the environmental regulations were not severe to justify greater efforts and commitment. In fact, it was cited as the 3rd most significant barriers for their green responsive initiative.

Previous findings e.g. ElTayeb et al. (2010) showed that the customer pressure was a driver for green purchasing among Malaysian customers. However, in this study, we found that such external pressure from the customers did not motivate the business industries in Perak to go green. The study by ElTayeb et al . (2010) focused on the green activities in relation to the suppliers meanwhile this current research went beyond the purchasing activity and looked into the overall green practices of the companies. As revealed in the path analysis results, the structural model had depicted the following four important drivers for green responsive initiative: requirement from regulations; the company's social responsibility; the pro-environmental organizational culture; and the organizational supports. Since the "pro-environmental organizational culture" was found to have the highest value of beta coefficient $(\beta)$, it meant that this factor played the most significant role in promoting the firms to adopt green practices. Thus, new approaches should be developed to involve major internal stakeholders in participating in strategic environmental planning and defining concrete targets and deadlines for green practices.

Regulatory pressure was found to be another key driver for green responsive initiative. Therefore, regulatory programme should be set up to ensure the compliance of environmental requirement and standard. There was a greater need to strengthen (1) the liability legislation in order to better compensate for damages to the environment in line with the 'polluter pays' principle, and (2) the enforcement capacity of local government agencies to carry out their new environmental functions. Indeed, there appeared to be a widely held scepticism in the enforcement of environmental laws in our country. We urge the local government to enhance regulatory scrutiny on the production and manufacturing industries. However, we believe that the business owners and management should be proactive in taking positive environmental actions. They should be more sensitive not only on the awareness of legislation but also on the benefits of going green, both in their business sustainability and society at large.

Meanwhile, we also call to alleviate the public concern near waste disposal facilities by adopting stricter emission standards, improving monitoring of emissions and paying adequate compensation; reduce government subsidisation of recycling by shifting greater responsibility to producers and creating adequate economic incentives to reduce waste generation; and to extend environment impact assessment (EIA) procedures to better integrate environmental concerns in sectorial projects and programme. Finally, we strongly believe that wider implementation of programme such as Eco-Labelling Scheme, MyHijau Label and GreenTAG could further promote the environmental friendly living culture and thus indirectly motivate greater commitment for businesses to go green.

\section{CONCLUSION}

This study aimed to identify the drivers and barriers for the business industry to implement green practices. It had implications for the academics, practitioners and policy makers. Firstly, it adds to the body of knowledge on green practices particularly within the Asian settings. Secondly, the results could be valuable to the managers by providing greater insights into green practices in Malaysian firms. The regulations, social responsibility, pro-environmental organizational culture and organizational supports were found to have 
significant impacts on the company's green initiatives. The environmental management standards of different organizations might vary in details and they are often subjected to the key elements of an environmental policy statement, objectives and targets, implementation procedures, internal monitoring, auditing and reporting. However, the adoption of ISO 14001 Environmental Management System (Specifications with guidance for use) was found as one of the most obvious determinations on a firm's commitment towards adopting green efforts.

Thirdly, the results could also help the government to further plan and enhance current guidelines and policies. In this study, we had highlighted the key internal and external barriers for firms to adopt green initiatives. The regulatory pressure is said to be a major driver for their environmental performance as it pushes the companies to respond and react. We believe that a more stringent monitoring from the government on the firm's compliance to the environmental regulations. Effective law enforcement is equally important to ensure the adherence towards the environmental standards by businesses.

Date of submission: August 2014

Date of acceptance: December 2014

\section{ACKNOWLEDGEMENT}

The authors would like to thank the Institute Darul Ridzuan (IDR) for financially supporting this research under KRA Perak Amanjaya Project.

\section{REFERENCES}

Andic, E, Yurt, O \& Baltacioglu, T 2012, 'Green supply chain: efforts and potential applications for the Turkish market', Resources, Conservation and Recycling, vol. 58, pp. 50-68.

Chen, CC, Shih, H-S, Shyur, H-J \& Wu, K-S 2012, 'A business Strategy selection of green supply chain management via an analytic network process', Computers and Mathematics with Applications, vol. 64, pp. 2544-2557.

CCIP 2014, Climate change performance index, $<$ https://germanwatch.org/en/download/ 8599. pdf $>$.

David, FS 2011, Strategic management: concept and cases, 14th edn, Pearson Prentice Hall International.

Diabat, A \& Govindan, K 2011, 'An analysis of the drivers affecting the implementation of green supply chain management', Resources, Conservation and Recycling, vol. 55, pp. 659-667.

ElTayeb, TK, Zailani, S \& Jayaraman, K 2010, 'The examination on the drivers for green purchasing adoption among EMS 14001 certified companies in Malaysia', Journal of Manufacturing Technology Management, vol. 21, no. 2, pp. 206-225.

Esty, DC \& Winston, AS 2009, Green to gold: how smart companies use environmental strategy to innovate, create value and build competitive advantage, John Wiley \& Sons Inc.

Hair Jr. JF, Black, WC, Babin, BJ \& Anderson, RE 2010, Multivariate data analysis: a global perspective, Pearson, London.

Hart, SL 2000, 'Beyond greening: strategies for a sustainable world', Harvard Business Review, vol. 72, no. 3, pp. 46-52.

Hong, P, Roh, JJ \& Rawski, G 2012, 'Benchmarking sustainability practices: evidence from manufacturing firms', Benchmarking: An International Journal, vol. 19, nos. 4/5, pp. 634-648.

Kleindorfer, PR, Singhal, K \& Van Wassenhove, LN 2005, 'Sustainable operations management', Production and Operations Management, vol. 14, pp. 482-492.

Loucks, ES, Martens, ML \& Cho, CH 2010 'Engaging small- and medium-sized businesses in sustainability', Sustainability Accounting, Management and Policy Journal, vol. 1, no. 2, pp. 178-200.

Orsato, RJ 2006, 'Competitive environmental strategies: when does it pay to be green?', California Management Review, vol. 48, no. 2, pp. 27-144. 
Perry, M \& Singh, S 2001, 'Corporate environmental responsibility in Singapore and Malaysia: the potential and limits of voluntary initiatives', Technology, Business and Society, United Nations Research Institute for Social Development.

Porter \& Van Der Linde 2000, 'Green and competitiveness: ending the stalement', Harvard Business Review, vol. 72, no. 3, pp. 131-167.
Raska, D \& Shaw, D 2012, 'When is going green good for company image?', Management Research Review, vol. 35, nos. 3/4, pp. 326-347.

Sani, S 1999, 'Environmental Management Issues and Challenges in the Next Millennium in Malaysia', Environmental Management Programme, Universiti Kebangsaan Malaysia, Bangi, Malaysia. 